Economics Development Analysis Journal

\title{
Pengaruh Harga Minyak Dunia, Nilai Tukar dan Inflasi terhadap Pertumbuhan Ekonomi Indonesia
}

Yaenal Arifin ${ }^{凶}$

Jurusan Ekonomi Pembangunan, Fakultas Ekonomi, Universitas Negeri Semarang

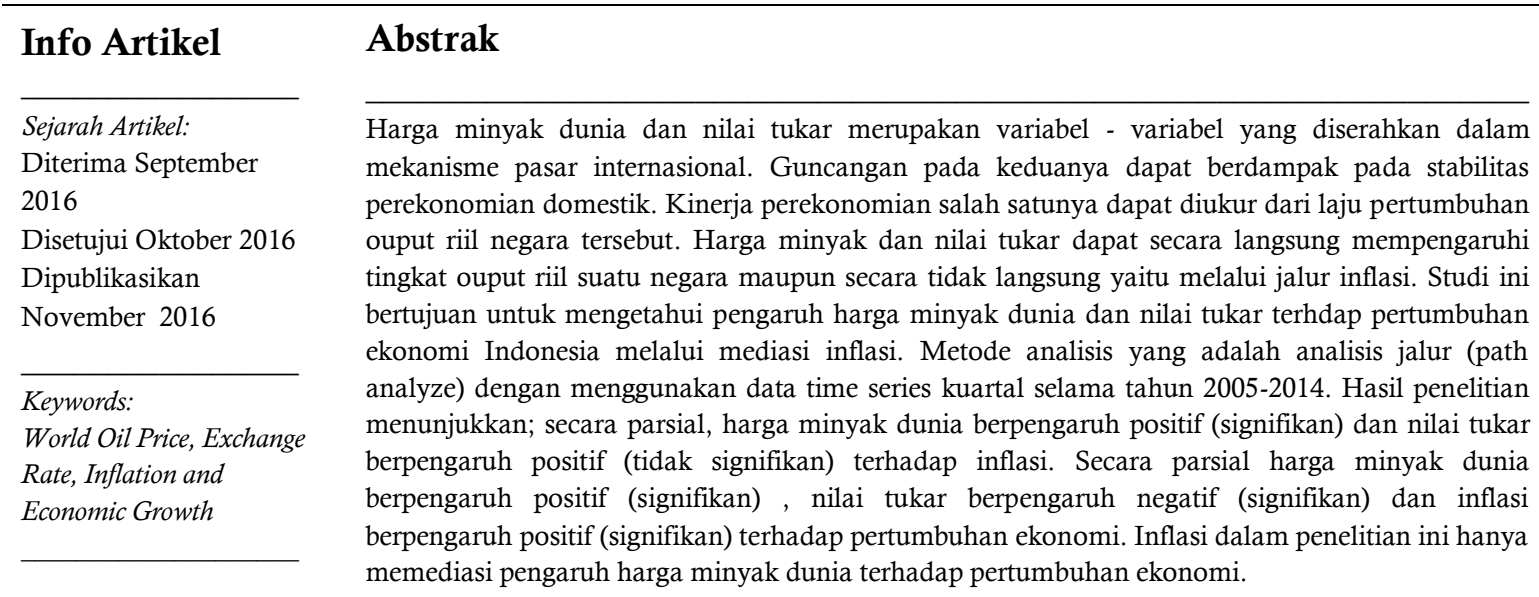

\begin{abstract}
World Oil prices and exchange rate are variables which controled by international market mechanism. Shocks on both can have an impact on the stability of the domestic economy. The economic performance measured in real output growth. Oil price and exchange rate directly affect a country's of real output growth and indirectly is through inflation. This study aims to determine the impact of oil price shock and exchange rate volatility on Indonesia's economic growth through inflation mediation. The method of analysis are using path analyze with quarterly time series data during the years 2005-2014. The result showed : partially, the oil price positively (significant) and positive exchange rate effect (not significant) on the inflation. Partially, world oil prices has a positive effect (significant), the exchange rate has a negative effect (significant) and the inflation has a positive effect (significant) to the economic growth. Inflation in this research just has a mediation the effect of world oil price to the economic growth.
\end{abstract}

\footnotetext{
$\triangle$ Alamat korespondensi:

Ruang Jurnal,Gedung L FE UNNES Sekaran Gunungpati

Semarang 50229, Indonesia

E-mail: yaenalar91@gmail.com
} ISSN 2252-6765 


\section{PENDAHULUAN}

Pertumbuhan ekonomi sering dikaitkan dengan energi, dimana energi merupakan salah satu dari berbagai input penting dalam proses produksi. Energi memberi dampak terhadap kegiatan ekonomi dalam skala mikro maupun makro. Terdapat hubungan ekonomi yang erat antara pertumbuhan ekonomi, harga minyak, pasar saham, nilai tukar, tingkat inflasi, dan tingkat suku bunga riil. Minyak merupakan salah satu energi sumber strategis untuk menjamin perkembangan industri modern dan ekonomi. Minyak mentah memiliki peran yang signifikan dalam pertumbuhan ekonomi suatu negara, sehingga harga minyak mentah internasional menjadi salah satu dari berbagai faktor yang diperhitungkan dalam mendukung produksi output. Fluktuasi harga minyak selalu dianggap sebagai barometer ekonomi di seluruh dunia, sehingga setiap perubahan harga minyak selalu menjadi isu panas untuk dibahas dalam lingkaran politik dan ekonomi di setiap negara.

Minyak dan fluktuasi harganya memberikan pengaruh yang sangat vital pada hampir semua aktivitas makroekonomi, karena minyak merupakan salah satu energi utama yang digunakan baik langsung maupun tidak langsung dalam memproduksi barang dan jasa. Minyak menjadi sumber energi teratas penggunaanya untuk menopang proses produksi dibandingkan dengan sumber energi lainnya, sehingga fluktuasi harga minyak sangat sensitif dengan kondisi perekonomian atau pertumbuhan ekonomi di setiap negara. Dan tidak ada satu negarapun yang tidak tergantung pada minyak dan mampu secara serta merta menurunkan konsumsinya akibat kenaikan harga tak terkecuali Indonesia.

R. J. Gordon menyatakan bahwa terjadinya fluktuasi pertumbuhan ekonomi disebabkan karena terjadinya pergeseran pada penawaran agregat, seperti terjadinya lonjakan harga minyak, kegagalan panen, perubahan iklim, ataupun perubahan kebijakan yang mempengaruhi sisi produksi. Guncangan akibat dari peningkat harga minyak akan menggeser AS ke kiri. Keseimbangan baru terbentuk pada tingkat output yang lebih rendah (stagnasi) dan harga yang lebih tinggi (inflasi). Selain harga minyak dunia yang terus bergejolak, guncangan eksternal lain yang turut mempengaruhi pertumbuhan ekonomi dan inflasi lainya adalah nilai tukar. Dalam perekonomian terbuka, pengaruh nilai tukar terhadap tingkat pertumbuhan dapat dilihat baik melalui jalur aggregate supply (AS), yakni melalui pembentukan capital dan knowledge, maupun aggregate demand (AD), yaitu melalui transaksi perdagangan internasional (ekspor-impor) dan investasi. Secara empiris, besarnya permintaan agregat tidak selalu sama dengan penawaran agregat. Jika terjadi selisih antara permintaan dan penawaran atau terjadi output gap maka akan memberi tekanan terhadap kenaikan hargaharga (inflasi) dari sisi domestik. Sementara itu, tekanan inflasi dari sisi luar negeri terjadi melalui pengaruh langsung dan tidak langsung perubahan nilai tukar terhadap perkembangan harga barang-barang yang diimpor.

Nilai tukar rupiah dalam beberapa tahun belakangan mengalami depresiasi yang cukup tajam terhadap dollar hingga mendekati $\mathrm{R}_{\mathrm{P}} 14.000$ per dollar. Ini adalah posisi terendah bagi mata uang rupiah terhadap US Dollar sejak krisis moneter tahun 1998, bahkan pada krisis global tahun 2008 sekalipun, posisi nilai tukar rupiah tidak anjlok sampai Rp 12,768 per US Dollar sebagai titik terendahnya, sebelum kemudian segera balik lagi ke level normalnya yakni Rp.9.000-an per US Dollar. Kondisi ini mendorong Bank Indonesia juga menaikkan SBI dari 7,53\% menjadi 7,70\% pada tanggal 20 April 2015 untuk memperkuat rupiah demi meredam laju inflasi gejolak akibat resesi global yang mengancam stabilitas ekonomi dalam negeri agar tidak seperti yang terjadi di Rusia. Sebagian besar depresiasi yang terjadi di Rusia mengakibatkan penurunan harga minyak (Dreger, 2016).

Transmisi pengaruh volatilitas harga minyak dunia dan nilai tukar rupiah dalam mempengaruhi tingkat output nasional dapat dilihat dari kontribusi keduanya dalam pembentukan inflasi. Pada tahun 2005 terjadi peningkatan inflasi sebesar 17,11 persen (yoy). 
Faktor yang mempengaruhi tingginya inflasi tahun 2005 yaitu meningkatnya harga minyak dunia yang diikuti dengan depresiasi nilai tukar rupiah. Kenaikan harga BBM sebanyak dua kali pada 2005, khususnya kenaikan kedua pada tanggal 1 Oktober 2005 meningkatkan ekspektasi inflasi yang tinggi di masyarakat.pergerakan nilai tukar rupiah juga terus melemah sepanjang tahun 2005. Jika pada bulan Mei nilai tukar rupiah berada pada kisaran 9.545 per dolar AS maka penutupan perdagangan 24 Agustus 2005 rupiah berada pada posisi 10.165 per dolar AS.

Dalam rangka mengendalikan ekspektasi dan sasaran inflasi jangka menengah panjang, Bank Indonesia menempuh kebijakan moneter yang cenderung ketat. Kebijakan moneter cenderung ketat tercermin pada kenaikan suku bunga secara bertahap. Pada Februari 2005 tercatat suku bunga sebesar 7,43 persen perlahan meningkat menjadi 8,25 persen pada Juni 2005 dan 12,75 persen pada Desember 2005 (Laporan Perekonomian Indonesia, 2005).

Berangkat dari fakta harga minyak internasional dan nilai tukar rupiah yang terus berfluktuasi serta merujuk pada beberapa hasil studi empiris terdahulu, kajian ini juga mencoba mengkaji bagaimana pengaruh volatilitas harga minyak dunia dan nilai tukar rupiah terhadap perekonomian Indonesia. Penelitian ini bertujuan untuk melihat pengaruh guncangan harga minyak dunia dan fluktuasi nilai tukar terhadap pertumbuhan ekonomi di Indonesia tahun 2005 - 2014.

\section{METODE PENELITIAN}

Jenis data yang digunakan dalam penelitian ini adalah data kuantitatif. Data kuantitatif merupakan data yang berbentuk bilangan. Sumber yang digunakan adalah data sekunder. Data sekunder adalah data yang diperoleh atau dikumpulkan oleh orang yang melakukan penelitian dari sumber-sumber yang telah ada. Sumber data yang digunakan adalah adalah dari Badan Pusat Statistik (BPS), Bank Indonesia, serta World Bank. Data yang digunakan merupakan data kuartal time series yakni dari tahun 2005Q1 sampai 2014 Q4 dengan jumlah $\mathrm{n}$ sebanyak 40 observasi. Pengolahan data pada skripsi ini menggunakan program SPSS 16.

\section{Analisis Jalur (Path Analyze)}

Analisis jalur merupakan perluasan dari analisis regeresi linier berganda, atau analisis jalur adalah penggunaan analisis regresi untuk menaksir hubungan kausalitas antar variabel (model kasual) yang telah ditetapkan sebelumnya berdasarkan teori.Apa yang dapat dilakukan oleh analisis jalur adalah menentukan pola hubungan antara tiga atau lebih variabel yang dan tidak dapat digunakan untuk mengkonfirmasi atau menolak hipotesis kausal imajiner. Didalam menggambarkan diagram jalur yang perlu diperhatikan adalah anak panah berkepala satu merupakan hubungan regresi dan anak panah berkepala dua adalah hubungan korelasi (Ghozali, 2011: 249-250). Model atau variabel yang diasumsikan telah memenuhi persyaratan analisis jalur meliputi data berskala interval, berdistribusi normal, pemenuhan asumsi lineritas, normalitas, homogen dan terbebas dari masalah multikolineritas. Pengujian akan dilakukan dua tahap, dimana pada tahap pertama akan diuji pengaruh harga minyak dunia dan nilai tukar terhadap terhadap inflasi, kemudian pada tahap kedua akan diuji pengaruh harga minyak, nilai tukar dan inflasi terhadap pertumbuhan output riil. Secara diagram bentuk hubungan antara ketiga variabel yang sedang diteliti tersebut dapat dilihat pada gambar 1.

Model ekonometrika yang digunakan adalah model analisis jalur (path analyse) dengan pengelolaan data menggunakan SPSS. Adapun persamaan regresinya sebagai berikut:

$$
\begin{aligned}
& X_{3}=\alpha+\beta_{1} X_{1}+\beta_{2} \operatorname{Ln} X_{2}+e_{1} \ldots \ldots \ldots \ldots \ldots \ldots(1) \\
& Y=\alpha+\beta_{1} X_{1}+\beta_{2} \operatorname{Ln} X_{2}+\beta_{3} X_{3}+e_{2} \ldots \ldots \ldots \ldots(2) \\
& \text { Keterangan: } \\
& X_{1}=\text { Variabel harga minyak dunia } \\
& \text { LnX } X_{2}=\text { Logaritma natural dari variabel nilai } \\
& \text { tukar }
\end{aligned}
$$


$\mathrm{X}_{3}=$ Variabel inflasi

$\mathrm{Y}=$ Variabel pertumbuhan ekonomi $\mathrm{e}_{1}=$ error sub struktur 1

$\mathrm{e}_{2}=$ error sub struktur 2

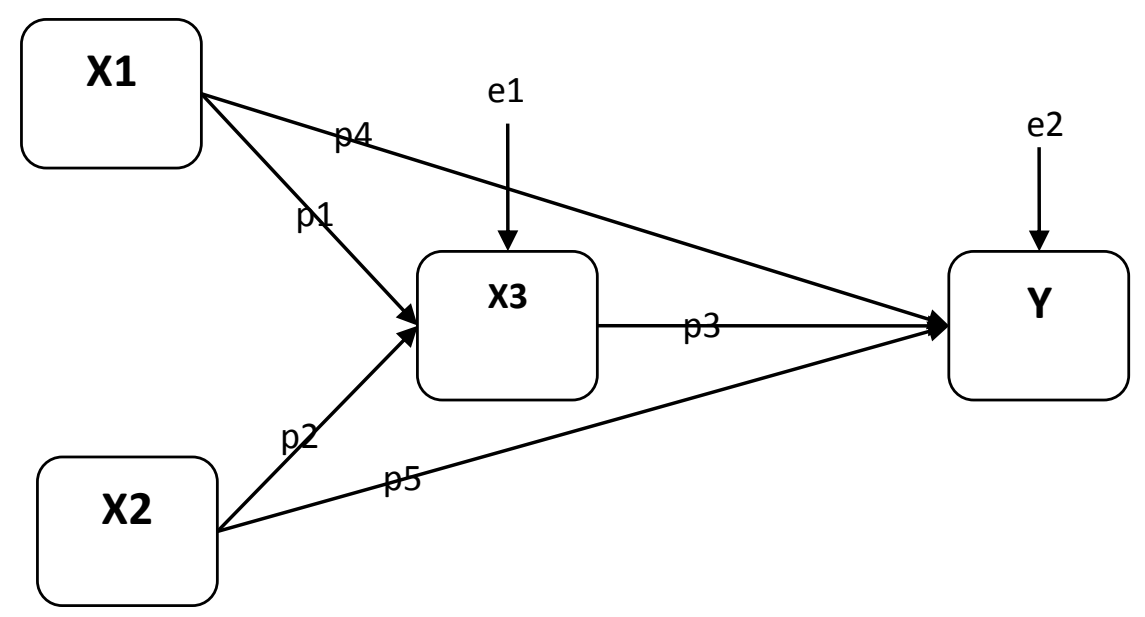

Sumber: Al Gozali (2013)

Gambar 1. Model Analisis Jalur (Path Analysis)

\section{HASIL DAN PEMBAHASAN}

\section{Analisis regresi tahap 1 (Sub struktur persamaan 1)}

Analisis regresi tahap satu mengkaji pengaruh harga minyak dunia $\left(X_{1}\right)$ dan nilai tukar $\left(\mathrm{X}_{2}\right)$ terhadap inflasi $\left(\mathrm{X}_{3}\right)$ dengan persaman regresinya adalah

$$
\mathrm{X}_{3}=\alpha+\beta_{1} \mathrm{X}_{1}+\beta_{2} \operatorname{Ln} \mathrm{X}_{2}+\mathrm{e}_{1}
$$

$$
\begin{aligned}
& \text { dimana: } \\
& \begin{array}{ll}
\mathrm{X}_{3} & =\text { Variabel inflasi } \\
\alpha & =\text { Konstanta } \\
\mathrm{X}_{1} & =\text { Variabel harga minyak dunia } \quad \beta_{1,2} \\
& =\text { Koefisien regresi } \\
\mathrm{LnX}_{2} & =\text { Log natural variabel nilai tukar } \mathrm{e}_{1} \\
& =\text { Standart error } 1
\end{array}
\end{aligned}
$$

\begin{tabular}{|c|c|c|c|c|c|c|}
\hline \multirow{2}{*}{\multicolumn{2}{|c|}{ Model }} & \multicolumn{2}{|c|}{ Unstandardized Coefficients } & $\begin{array}{c}\text { Standardized } \\
\text { Coefficients }\end{array}$ & \multirow[b]{2}{*}{$\mathrm{t}$} & \multirow[b]{2}{*}{ Sig. } \\
\hline & & B & Std. Error & Beta & & \\
\hline \multirow[t]{3}{*}{1} & (Constant) & $-2.636 \mathrm{E}-5$ & .153 & & .000 & 1.000 \\
\hline & $\mathrm{X} 1$ & .328 & .155 & .328 & 2.115 & .041 \\
\hline & Ln_X2 & .097 & .155 & .097 & .623 & .537 \\
\hline
\end{tabular}

Hasil regresi sub struktur 1 dapat dilihat pada tabel dibawah ini.

Tabel 1. Regresi Berganda Tahap 1

Coefficients $^{\mathrm{a}}$

a. Dependent Variable: X3

Berdasarkan tabel 6 di atas diperoleh persamaan regresi berganda sebagai berikut: X3 $=-0,000026+0,328 \mathrm{X}_{1}+0,97 \mathrm{X}_{2}$. Persamaan regresi tersebut mempunyai makna sebagai berikut:
Konstanta $=0,000026$, artinya jika variabel harga minyak dunia $\left(\mathrm{X}_{1}\right)$ dan nilai tukar $\left(\mathrm{X}_{2}\right)$ sama dengan nol, maka nilai tingkat inflasi $\left(X_{3}\right)$ sebesar $-0,000026$ persen.

Koefisien Harga Minyak Dunia $=0,328$, artinya jika variabel harga minyak dunia $\left(\mathrm{X}_{1}\right)$ 
meningkat mengalami sebesar satu dollar per barel, maka tingkat inflasi meningkat sebesar 0,328 persen.

Koefisien Nilai Tukar $=0,097$, artinya jika variabel nilai tukar mengalami kenaikan sebesar satu poin, maka tingkat inflasi meningkat sebesar 0,097 persen.

Analisis regresi tahap 2 (Sub struktur persamaan 2)

Analisis regresi tahap 2 mengkaji pengaruh harga minyak dunia $\left(\mathrm{X}_{1}\right)$, nilai tukar $\left(\mathrm{X}_{2}\right)$ dan inflasi $\left(\mathrm{X}_{3}\right)$ terhadap pertumbuhnan ekonomi (Y) dengan persamaan regresinya adalah :

$$
Y=\alpha+\beta_{1} X_{1}+\beta_{2} \operatorname{Ln} X_{2}+\beta_{3} X_{3}+e_{2}
$$

Dimana :

$\mathrm{Y} \quad=$ Variabel pertumbuhan ekonomi

$\alpha=$ Konstanta

$\mathrm{X}_{1} \quad=$ Variabel harga minyak dunia

$\beta_{1,2,3}=$ Koefisien regresi

$\mathrm{LnX}_{2}=$ Log natural variabel nilai tukar

$\mathrm{e}_{2} \quad=$ Standart error 2

$\mathrm{X}_{3} \quad=$ Variabel Inflasi

Ringkasan dari output regresi tahap 2 dapat dilihat pada tabel diabawah ini.

Tabel 2. Regresi Berganda Tahap 2

\begin{tabular}{|c|c|c|c|c|c|c|}
\hline \multicolumn{7}{|c|}{ Coefficients $^{\mathrm{a}}$} \\
\hline & & \multicolumn{5}{|c|}{ Standardized } \\
\hline & & Unstandardizec & Coefficients & Coefficients & & \\
\hline \multicolumn{2}{|l|}{ Model } & B & Std. Error & Beta & $\mathrm{t}$ & Sig. \\
\hline \multirow[t]{4}{*}{1} & (Constant) & $-5.580 \mathrm{E}-6$ & .119 & & .000 & 1.000 \\
\hline & $\mathrm{X} 1$ & .276 & .128 & .276 & 2.164 & .037 \\
\hline & Ln_X2 & -.486 & .121 & -.486 & -4.015 & .000 \\
\hline & $\mathrm{X} 3$ & .342 & .128 & .342 & 2.677 & .011 \\
\hline
\end{tabular}

a. Dependent Variable: Y

Berdasarkan tabel 7 di atas diperoleh persamaan regresi berganda sebagai berikut: $\mathrm{Y}=$ - $0,0000055+0,276 \mathrm{X}_{1}-0,486 \mathrm{X}_{2}+0,342 \mathrm{X}_{3}$. Persamaan regresi tersebut mempunyai makna sebagai berikut:

Konstanta $=-0,0000055$, artinyam jika variabel harga minyak dunia, nilai tukar dan inflasi sama dengan nol, maka nilai pertumbuhan ekonomi sebesar 0,0000055 persen.

Harga Minyak Dunia $\left(\mathrm{X}_{1}\right)=0,276$, artinya jika variabel harga minyak dunia mengalami kenaikan sebesar satu dollar, maka tingkat pertumbuhan ekonomi meningkat sebesar 0,276 persen
Nilai Tukar $\left(\mathrm{X}_{2}\right)=-0.486$, artinya jika variabel nilai tukar mengalami kenaikan sebesar satu persen, maka tingkat pertumbuhan ekonomi menurun sebesar 0,486 persen.

Inflasi $\left(\mathrm{X}_{3}\right)=0,342$, artinya jika variabel inflasi mengalami kenaikan sebesar satu persen, maka tingkat pertumbuhan ekonomi meningkat sebesar 0,342 persen

\section{Pembentukan Analisis Jalur}

Dari analisis regresi satu dan analisis regresi 2 diperoleh analasis jalur sebagai berikut. 


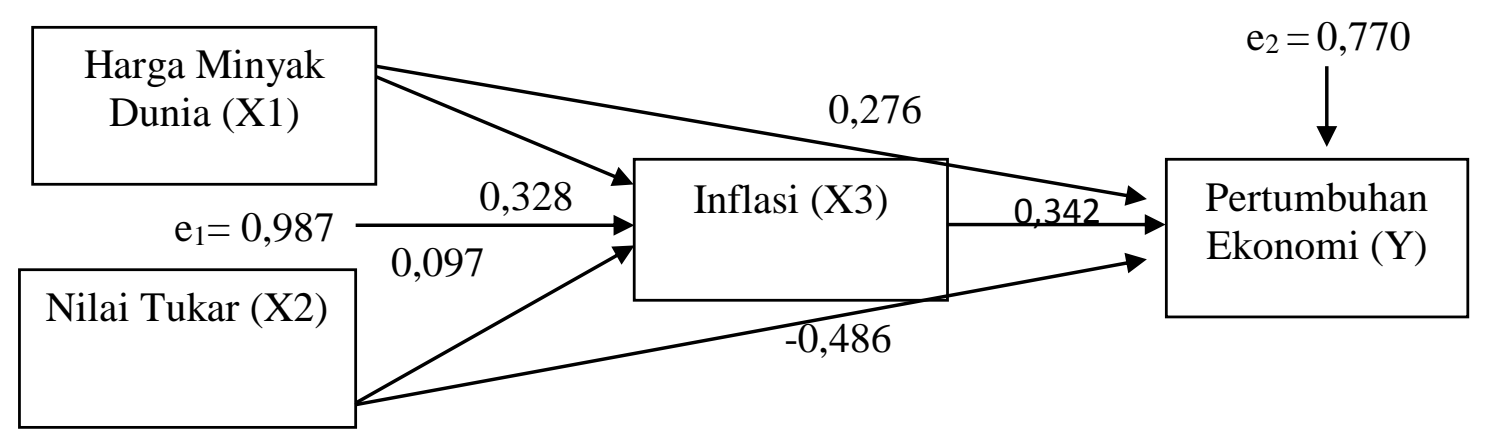

Gambar 2. Pembentukan Analisis Jalur

Dari gambar diatas diperoleh keterangan dunia dan nilai tukar terhadap pertumbuhan besarnya pengaruh langsung harga minyak ekonomi melalui inflasi dapat dilihat pada tabel dibawah ini.

Tabel 3. Besaran pengaruh langsung dan tak langsung

\begin{tabular}{ccccccccccc}
\hline \hline Variabel & \multicolumn{8}{c}{ Harga Minyak Dunia } & \multicolumn{1}{c}{ Nilai Tukar } \\
\hline Pengaruh langsung & 0.276 & $\mathrm{x}$ & 0.276 & $=$ & $7.61 \%$ & -0.486 & $\mathrm{x}$ & -0.486 & $=23.61 \%$ \\
\hline $\begin{array}{c}\text { Pengaruh tidak } \\
\text { Langsung }\end{array}$ & 0.328 & $\mathrm{x}$ & 0.342 & $=$ & $11.21 \%$ & 0.097 & $\mathrm{x}$ & 0.342 & $=$ & $3,3 \%$ \\
\hline
\end{tabular}

\section{Pengaruh total $7.61+11.21=16.82 \%$}

$$
23.61+3.3=26.94 \%
$$

Dari tabel diatas diperoleh keterangan besarnya pengaruh langsung harga minyak dunia terhadap pertumbuhan ekonomi adalah $7,61 \%$, pengaruh tidak langsung melalui mediasi inflasi adalah sebesar $11,21 \%$, dan total pengaruhnya adalah $16,82 \%$. Sedangkan pengaruh langsung nilai tukar terhadap pertumbuhan ekonomi adalah 23.61, pengaruh tidak langsung melalui mediasi inflasi adalah sebesar 3,3\%, sedangkan total pengaruh nilai tukar adalah sebesar $26.94 \%$.

\section{Uji Parsial (t statistic)}

\section{Uji t Variabel Inflasi (X3)}

Uji hipotesis dalam penelitian ini diproksikan dengan uji $\mathrm{t}$ atau uji parsial. Uji $\mathrm{t}$ dilakukan untuk mengetahui apakah secara individu (parsial) variabel independen mempengaruhi variabel dependen secara signifikan atau tidak. Berdas arkan hasil pengolahan data lampiran 6 dan 7, diperoleh hasil sebagai berikut :

Tabel 4. Uji Parsial Variabel Independen terhadap Inflasi (X3)

\begin{tabular}{|c|c|c|c|c|c|}
\hline Uji & Variabel & t hitung & Tanda & t tabel & Sig \\
\hline & $\mathrm{X}_{1}$ & & & & \\
\hline $\mathrm{H}_{1}$ & $\begin{array}{c}\text { terhadap } \\
\mathrm{X}_{3}\end{array}$ & 2,115 & $>$ & 2,026 & 0,041 \\
\hline $\mathrm{H}_{2}$ & $\begin{array}{c}\mathrm{X}_{2} \\
\text { terhadap } \\
\mathrm{X}_{3}\end{array}$ & 0.623 & $<$ & 2,026 & 0,537 \\
\hline
\end{tabular}

Dengan tingkat kepercayaan $=95 \%$ atau $1=36$, serta pengujian dua sisi diperoleh dari $(\alpha)=0,05$. Derajat kebebasan $(\mathrm{df})=\mathrm{n}-\mathrm{k}-1=40-3-\quad$ nilai ttabel $=2,028$. 
Hasil pengujian diperoleh hasil bahwa harga minyak dunia $\left(\mathrm{X}_{1}\right)$ berpengaruh positif terhadap inflasi $\left(\mathrm{X}_{3}\right)$. Berdasarkan tabel diatas diperoleh keterangan untuk variabel harga minyak dunia diperoleh nilai thitung $=2,115$ dengan sig 0,041 $<0,05$ jadi Hal dierima dengan kata harga minyak dunia berpengaruh terhadap inflasi

Hasil pengujian diperoleh hasil bahwa nilai tukar $\left(\mathrm{X}_{2}\right)$ tidak berpengaruh signifikan terhadap inflasi $\left(\mathrm{X}_{3}\right)$. Untuk variabel nilai tukar diperoleh nilai thitung $=0.623$ dengan sig 0.537
$>0,05$ jadi $\mathrm{Ha} 2$ ditolak dengan kata lain nilai tukar tidak berpengaruh signifikan terhadap inflasi.

\section{Uji t Variabel Pertumbuhan ekonomi (Y)}

Pada model regresi kedua, uji t dilakukan untuk mengetahui apakah secara individu (parsial) variabel independen mempengaruhi variabel dependen pertumbuhan ekonomi (Y) secara signifikan atau tidak.

Tabel 5. Uji Parsial Variabel Independen terhadap Pertumbuhan Ekonomi

\begin{tabular}{cccccc}
\hline Uji & Variabel & t hitung & Tanda & t tabel & Sig \\
\hline $\mathrm{H}_{3}$ & $\mathrm{X}_{1}$ & & & & \\
& terhadap & 2,164 & $>$ & 2,028 & 0,037 \\
$\mathrm{Y}$ & & & & \\
$\mathrm{X}_{2}$ & & & & \\
$\mathrm{H}_{4}$ & $\begin{array}{c}\text { terhadap } \\
\text { Y }\end{array}$ & 4.015 & $>$ & 2,028 & 0,000 \\
$\mathrm{H}_{5}$ & $\begin{array}{c}\mathrm{X} \\
\text { terhadap } \\
\end{array}$ & 2,677 & $>$ & 2,028 & 0,011 \\
\hline
\end{tabular}

Sumber : Data diolah

Hasil pengujian diperoleh hasil bahwa harga minyak dunia $\left(\mathrm{X}_{1}\right)$ berpengaruh positif terhadap pertumbuhan ekonomi (Y). Berdasarkan tabel 10. diperoleh keterangan untuk variabel harga minyak dunia diperoleh nilai thitung $=2,164$ dengan sig $0,037<0,05$ jadi Ha3 dierima dengan kata lain harga minyak dunia berpengaruh terhadap pertumbuhan ekonomi

Sedangkan nilai tukar $\left(\mathrm{X}_{2}\right)$ berpengaruh signifikan terhadap pertumbuhan ekonomi (Y). Untuk variabel nilai tukar diperoleh nilai thitung $=4.015$ dengan sig $0.000>0,05$

Inflasi $\left(\mathrm{X}_{3}\right)$ berpengaruh signifikan terhadap pertumbuhan ekonomi (Y). Untuk variabel inflasi diperoleh nilai thitung $=2.667$ dengan sig $0.011>0,05$ jadi $\mathrm{Ha} 5$ diterima dengan kata lain inflasi berpengaruh signifikan terhadap pertumbuhan ekonomi.

\section{Uji Sobel (Sobel Test)}

Pengujian hipotesis mediasi dapat dilakukan dengan prosedur yang dikembangkan oleh Sobel (1982) dalam Ghozali (2011: 248) dan dikenal dengan Uji sobel (Sobel Test). Uji Sobel dilakukan dengan cara menguji kekuatan pengaruh tidak langsung variabel independent $\left(\mathrm{X}_{1}, \mathrm{X}_{2}\right)$ kepada variabel dependen $(\mathrm{Y})$ melalui variabel intervening $\left(\mathrm{X}_{3}\right)$. Berikut cara perhitungannya:

\section{Pengaruh harga minyak dunia melalui inflasi terhadap pertumbuhan ekonomi}

1) Menghitung pengaruh langsung dan tidak langsung

Pengaruh Langsung $\quad=0,276 \times 0,276$

$=0.076$

$\underline{\text { Pengaruh Tidak Langsung } \quad=0.328 \times 0.342}$

$=0.112$

Pengaruh Total

$=0.188$

2) Menghitung dengan Sobel Test

$\mathrm{Sab}$

$\sqrt{0.342^{2} 0.155^{2}+0.328^{2} 0.128^{2}+0.155^{2} 0.128^{2}}=$ 0.015 
3) Menghitung nilai $t$ statistik pengaruh intervening

$$
\mathrm{t}=\frac{0.328 \times 0.342}{0.015}=7.610
$$

Berdasarkan hasil perhitungan diperoleh nilai $\mathrm{t}$ hitung sebesar 7.610 lebih besar dari $\mathrm{t}$ tabel yaitu 2.026 dengan tingkat signifikansi 0,05 . Dengan demikian inflasi secara signifikan memediasi pengaruh harga minyak dunia terhadap pertumbuhan ekonomi. Hal ini berarti Ha6 yang menyatakan harga minyak dunia berpengaruh terhadap pertumbuhan ekonomi melalui inflasi diterima.

\section{Pengaruh nilai tukar melalui inflasi terhadap pertumbuhan ekonomi.}

Berdasarkan hasil uji t yang dilakukan diketahui bahwa nilai tukar tidak berpengaruh signifkan terhadap variabel inflasi. Dengan demikian dapat disimpulkan bahwa inflasi secara tidak memediasi pengaruh nilai tukar terhadap pertumbuhan ekonomi. Hal ini berarti Ha7 yang menyatakan nilai tukar berpengaruh terhadap pertumbuhan ekonomi melalui inflasi ditolak

\section{Pembahasan}

Pengaruh Variabel Harga Minyak Dunia $\left(X_{1}\right)$ terhadap Inflasi $\left(\mathrm{X}_{3}\right.$

Hasil penelitian menunjukan harga minyak dunia berpengaruh positif terrhadap tingkat inflasi. Berdasarkan hasil pengujian secara parsial dan uji signifikansi, bahwa variabel harga minyak dunia berpengaruh positif dan signifikan terhadap inflasi. Hasil ini terlihat dari nilai $t$ hitung $>t$ tabel $(2,115>2,026)$ dan taraf signifikansi sebesar 0,041 lebih kecil dari 0,050 dan nilai koefisien positif. Hal ini menunjukkan bahwa naiknya harga minyak dunia berpengaruh terhadap naiknya laju inflasi. Besarnya pengaruh harga minyak dunia terhadap inflasi adalah 0,328 (nilai koefisien). Artinya, jika variabel harga minyak dunia mengalami kenaikan sebesar satu persen, maka tingkat inflasi meningkat sebesar 0,328 persen.

\section{Pengaruh Nilai Tukar $\left(\mathrm{X}_{2}\right)$ terhadap Inflasi $\left(\mathrm{X}_{3}\right)$}

Berdasarkan hasil pengujian pengujian secara parsial dan uji signifikansi, dapat dikatakan bahwa nilai tukar berpengaruh tidak signifikan terhadap inflasi pada tahun 2005 2014. Nilai signifikansi nilai tukar terhadap inflasi sebesar 0,537 >0,050. Hal ini berarti apresiasi (menguatnya) atau depresiasi (melemahnya) nilai tukar rupiah terhadap dollar Amerika bank tidak berpengaruh terhadap pergerakan laju inflasi periode 2005 - 2014.

\section{Pengaruh Harga Minyak Dunia $\left(X_{1}\right)$ terhadap Pertumbuhan Ekonomi (Y)}

Berdasarkan hasil pengujian secara parsial dan uji signifikansi, bahwa variabel harga minyak dunia berpengaruh positif dan signifikan terhadap pertumbuhan ekonomi. Hasil ini terlihat dari nilai $\mathrm{t}$ hitung $>\mathrm{t}$ tabel $(2,164>$ 2,028 ) dan taraf signifikansi sebesar 0,037 lebih kecil dari 0,050 dan nilai koefisien positif. Hal ini menunjukkan bahwa nilai harga minyak dunia yang tinggi berpengaruh terhadap naiknya pertumbuhan ekonomi. Besarnya pengaruh harga minyak dunia terhadap pertumbuhan ekonomi adalah 0,276 (nilai koefisien). Artinya, jika variabel harga minyak dunia mengalami kenaikan sebesar satu dollar, maka tingkat pertumbuhan ekonomi meningkat sebesar 0,276 persen.

\section{Pengaruh Nilai Tukar $\left(X_{2}\right)$ terhadap Pertumbuhan Ekonomi (Y)}

Hasil penelitian menunjukan nilai tukar berpengaruh signifikan terhadap pertumbuhan ekonomi. Hasil ini terlihat dari nilai $\mathrm{t}$ hitung $>\mathrm{t}$ tabel $(4,015>2,028)$ dan taraf signifikansi sebesar 0,000 lebih kecil dari 0,050 dan nilai koefisien negatif. Hal ini menunjukkan bahwa depresiasi nilai nilai tukar terhadap turunnya pertumbuhan ekonomi. Besarnya pengaruh nilai tukar terhadap pertumbuhan ekonomi adalah 0,486 (nilai koefisien). Artinya, nilai tukar mengalami depresiasi sebesar satu persen, maka tingkat pertumbuhan ekonomi menurun sebesar 0,486 persen. 
Pengaruh Inflasi $\left(\mathrm{X}_{3}\right)$ terhadap Pertumbuhan Ekonomi (Y)

Hasil penelitian menunjukan inflasi berpengaruh signifikan terhadap pertumbuhan ekonomi. Hasil ini terlihat dari nilai $\mathrm{t}$ hitung $>\mathrm{t}$ tabel $(2,677>2,028)$ dan taraf signifikansi sebesar 0,011 lebih kecil dari 0,050 dan nilai koefisien positif. Hal ini menunjukkan bahwa naiknya inflasi juga diikuti oleh naiknya pertumbuhan ekonomi. Besarnya pengaruh nilai tukar terhadap pertumbuhan ekonomi adalah 0,342, (nilai koefisien). Artinya, inflasi mengalami kenaikan sebesar satu persen, maka tingkat pertumbuhan ekonomi menurun sebesar 0,34 persen.

\section{Pengaruh Harga Minyak $\left(X_{1}\right)$ Dunia terhadap Pertumbuhan Ekonomi (Y) melalui mediasi inflasi $\left(\mathrm{X}_{3}\right)$}

Inflasi memediasi pengaruh harga minyak dunia terhadap pertumbuhan ekonomi periode 2005-2014. Hal ini dibuktikan di dengan Uji Sobel (Sobel Test) yang menunjukan hasil perhitungan nilai $\mathrm{t}$ statistik pengaruh mediasi sebesar 7.610 lebih besar dari t tabel yaitu 2.026 dengan tingkat signifikansi 0,05. Sedangkan besarnya pengaruh langsung harga minyak dunia terhadap pertumbuhan ekonomi adalah $7,61 \%$, pengaruh tidak langsung melalui mediasi inflasi adalah sebesar $11,21 \%$, dan total pengaruhnya adalah $16,82 \%$.

Pengaruh langsung harga minyak dunia terhadap pertumbuhgan ekonomi adalah sebesar Sedangkan besarnya pengaruh tidak langsung harga minyak dunia terhadap pertumbuhan ekonomi melalui inflasi adalah 11,21\%.

Pengaruh Nilai tukar $\left(\mathrm{X}_{2}\right)$ terhadap Pertumbuhan Ekonomi (Y) melalui mediasi Inflasi $\left(\mathrm{X}_{3}\right)$

Berdasarkan hasil uji t yang dilakukan diketahui bahwa nilai tukar tidak berpengaruh signifkan terhadap variabel inflasi. Sehingga dapat dikatakan Inflasi tidak memediasi pengaruh nilai tukar terhadap pertumbuhan ekonomi periode 2005 -2014. Dari tabel diatas diperoleh keterangan besarnya pengaruh langsung nilai tukar terhadap pertumbuhan ekonomi adalah
23,61\% dan besarnya pengaruh tidak langsung nilai tukar terhadap pertumbuhan ekonomi melalui inflasi adalah 3,3\%, sedangkan total pengaruh nilai tukar adalah sebesar $26.94 \%$

\section{SIMPULAN}

Berdasarkan hasil penelitian dan pembahasan disimpulkan bahwa secara parsial pada regresi sub struktur persamaan 1, harga minyak dunia berpengaruh signifikan terhadap inflasi sedangkan nilai tukar berpengaruh tidak signifikan inflasi. Pada regresi sub struktur persamaan 2, harga minyak, nilai tukar dan inflasi berpengaruh signifikan terhadap pertumbuhna ekonomi. Inflasi memediasi pengaruh harga minyak dunia terhadap pertumbuhan ekonomi.

Pemerintah sebagai pembuat kebijakan harus mampu memperhatikan perkembangan harga minyak dunia, mengingat pengaruh fluktuasi harga minyak sangat berbengaruh besar terhadap pembentukan laju inflasi dan laju pertumbuhan ekonomi. Indonesia yang telah keluar dari OPEC harus memproioritaskan pemenuhan kebutuhan konsumsi dalam negeri ketimbang menjualnya ke pasar internasional. Variabel nilai tukar juga memiliki pengaruh signifikan terhadap laju pertumbuhan ekonomi. Penerapan sistem nilai tukar mengambang bebas (free floating system) diharapkan mampu mendorong pertumbuhan ekonomi melalui jalur nilai tukar. Namun dengan penerapan ini tugas otoritas moneter (Bank Indonesia) dalam menjaga stabilitas ekonomi akibat guncangan eksternal menjadi semakin berat karena guncangan pada perekonomian dunia akan secara langsung ditransmisikan kepada perekonomian domestik. Peran kestabilan nilai tukar sangat penting dalam mencapai stabilitas harga dan sistem keungan. Oleh karena itu Bank Indonesia perlu menjalankan kebijakan nilai tukar untuk mengurangi volatilitas nilai tukar yang berlebihan bukan mengarahkan nilai tukar pada level tertentu. Terkait inflasi, sejauh laju inflasi masih berada di bawah dua digit atau 10 $\%$ memiliki dampak yang positif terhadap laju pertumbuhan ekonomi. Untuk itu pemerintah 
diharapkan untuk terus menjaga laju inflasi dan memperhatikan variabel yang mempengaruhi inflasi seperti harga minyak dunia yang ditransmisikan ke dalam harga Bahan Bakar Minyak (BBM) dalam negeri.

\section{DAFTAR PUSTAKA}

Aprileven, H. 2015. Pengaruh Faktor-Faktor Ekonomi Terhadap Inflasi di Indonesia Yang Dimediasi Oleh Jumlah Uang Beredar (Pendekatan Path Analysis). Economics Development Analysis Journal, 4

Bank Indonesia (BI). 2014. Statistik Ekonomi dan Keuangan Indonesia (SEKI) periode $2000-2014$

Bank Indonesia. 2005. Laporan Perekonomian Indonesia Tahunan.

Boediono. 2011. Ekonomi Moneter, Seri Sinopsis Pengantar Ilmu Ekonomi No.5. Yogyakarta: BPFE.

Dreger, Christian, et al. 2016. Between the hammer and the anvil: The impact of economic sanctions and oil prices on Russia's ruble. Journal of Comparative Economics, 44, pp.295308.

Gordon, Robert. 1990. Philips Curve Now and Then. Cambrige. National Bureau of Economic Research. Working Paper No. 3393
Gozali, Imam. 2011. Semarang : Universitas Diponegoro.

http://www.bi.go.id/web/id/moneter/laporan +perekonomian+tahunan+2005.

http://www.bi.go.id/web/id/moneter/laporan +perekonomian+tahunan+2007.

International Energy Agency (IEA). 2008. World Aplikasi Analisis Multivariate Dengan Program IBM SPSS19 (edisi kelima). Energy Outlook 2008. Paris.

Narayan, Paresh Kumar, et al. 2014. Do oil prices predict economic growth? New global evidence. Energy Economics, 41, pp.137-146.

Nizar, Muhammad. 2012. The Impact of World Oil Prices Fluctuation on Indonesia's Economy. Buletin Ilmiah Litbang Perdagangan, Vol.6 No.2. Pusat Kebijakan Ekonomi Makro, Badan Kebijakan Fiskal, Kementerian Keuangan-RI.

Mankiw, N. G. 2003. Teori Makroekonomi. terj. Imam Nurmawan, Jakarta: Erlangga.

Pradhan, Rudra P., et al. 2015. The dynamics of economic growth, oil prices, stock market depth, and other macroeconomic variables: Evidence from the G-20 countries. International Review of Financial Analysis, 39, pp.84-95.

Sukirno, Sadono. 2002. Pengantar Teori Makroekonomi. Jakarta: PT Raja Grafindo Persada. 